\title{
Peter Nolan, Is China Buying the World?
}

Cambridge, UK, Polity Press, 2012, 147 pp.

\section{Yu Tao}

\section{(2) OpenEdition}

\section{Journals}

Electronic version

URL: http://journals.openedition.org/chinaperspectives/6293

DOI: 10.4000/chinaperspectives.6293

ISSN: 1996-4617

\section{Publisher}

Centre d'étude français sur la Chine contemporaine

\section{Printed version}

Date of publication: 1 September 2013

Number of pages: 93-94

ISSN: 2070-3449

\section{Electronic reference}

Yu Tao, "Peter Nolan, Is China Buying the World? », China Perspectives [Online], 2013/3 | 2013, Online since 01 September 2013, connection on 23 September 2020. URL : http://journals.openedition.org/ chinaperspectives/6293; DOI : https://doi.org/10.4000/chinaperspectives.6293

(C) All rights reserved 
between mainland China and Taiwan, Hong Kong, and Macau might facilitate the normalisation process toward the peaceful resolution of the crossstraits issue, and strengthen confidence over "one country, two systems" in the two Special Administration Regions. Secondly, China will encounter severe challenges to its strategic transition from "keeping a low international profile" (taoguang yanghui) to "rising peacefully" (heping jueqi). On the one hand, there are increasing protests against China's export dumping, natural resource exploitation, and expatriate labour both in developed and developing countries. On the other hand, there is growing criticism of its indifference to issues of good governance such as corruption and human rights and to issues of responsible involvement as a great power in promoting global security.

In sum, this volume is a clearly written, well-informed, and forward-looking book that helps understand the complexities and challenges of China's development. Two years after the publication of this reasoned work, the sober prognoses made by Shambaugh and his contributors have generally proved quite tenable and convincing. The historic leadership succession at the $18^{\text {th }}$ National Party Congress did not bring abrupt systemic change. And the ongoing Euro crisis has proved to be not an unbearable external economic shock, but rather a chance for China to claim leadership in resolving the international economic crisis without simply following Western prescriptions. It is reasonable to agree with the authors' prognostication that in the next few years, China will handle those domestic and international challenges relatively well.

I Ding Hui is an independent researcher who in 2012 obtained his PhD from Universität Heidelberg, Institut für Politische Wissenschaft, Germany (dingdanghui@hotmail.com).

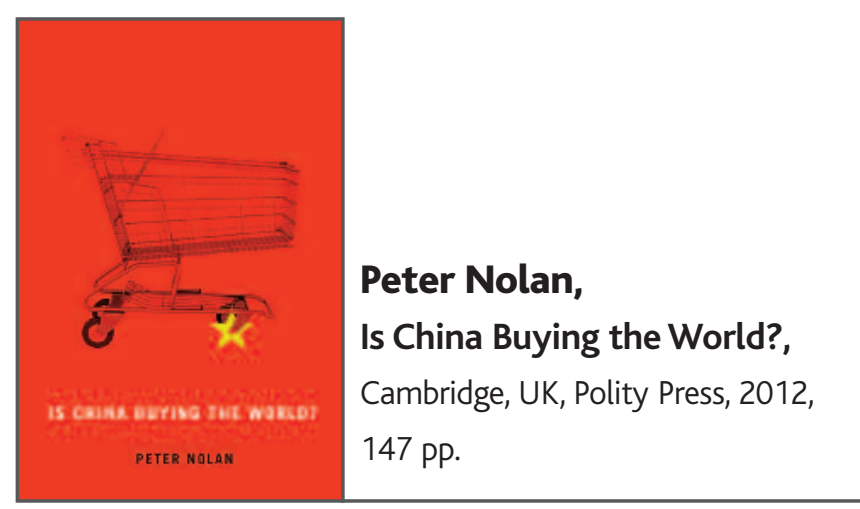

\section{YU TAO}

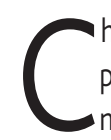
hina's remarkable economic performance since the late 1970s is impressive in many ways. The constant high growth rate lasting for more than three decades is in itself a miracle. The hugely successful development of the world's most populous country is an incredible achievement, especially considering that prior to this accomplishment China had suffered repeated foreign invasions and domestic turbulence for more than a century. The communist regime's survival and prosperity in China after the end of the Cold War also challenges the prediction many scholars made soon after the fall of the Berlin Wall and the collapse of the Soviet Union.

Contrary to the once popular claim that China would soon follow the example of the disbanded Soviet Union and its European satellite states, the
"Oriental Giant Dragon" has now emerged as one of the world's most influential countries. China is the second largest economy in the world, and its significant role in the international arena has become increasingly obvious. Under these circumstances, it is unsurprising that many scholars, politicians, and business elites have become captivated by China's dramatic rise in the last three-and-a-half decades. Mainstream economists and China specialists in academia are heatedly debating whether the country's growth is stable and sustainable. Meanwhile, to a considerable number of political and business leaders in developed countries, the rapid rise of a state led by a communist party presents an urgent threat that, if not tackled, will soon destabilise the established economic and political order of the international community.

Such a myth is taken on and cleared up by Peter Nolan, the Sinyi Professor of Chinese Management at the University of Cambridge and one of the world's most prominent experts on China's economy, in his new volume Is China Buying the World?.Through answering the fascinating question raised by its title, this book convinces its readers that a richer and stronger China is not buying the world. Contrary to the conventional wisdom that accuses China of taking over companies in the developed world through acquisitions and/or investments, Nolan's comparison of the scales and strategies of large Chinese and Western firms in several key industries, including manufacturing and finance, suggests that China's economic influence is relatively weak outside its soil, and he further argues that China's economic expansion faces a series of tough obstacles. Therefore, according to Nolan, "China has not yet bought the world and shows little sign of doing so in the near future" (p. 143).

Nolan's new volume clearly targets a wide audience. Yet, as a serious academic book, it is based on the author's original research into empirical data collected from big firms. After a compelling introduction highlighting the significance of China's rise and some related concerns and debates, this book consists of four chapters and a conclusion. The brief first chapter raises two key questions that run through the entire volume: who are "we" (by which Nolan refers to high-income countries) and who are "they" (by which Nolan means the developing world with China at the forefront). The definitions of and boundary between "we" and "they" used to be clear and explicit. As Nolan shows in the second and third chapters, however, this situation has been fundamentally changed by the deepening capitalist globalisation.

According to Nolan, around the time that China shifted from political campaigns to economic development, the world economy "entered a new phase of capitalist globalisation" (p. 15). As shown by some detailed and explicated figures that Nolan calculates through data from several leading manufactures in the automobile and beverage industries, this new wave of globalisation, driven by the liberalisation of trade and capital flows, has enabled many large firms to accelerate their international expansion, either through intense merger and acquisition activities or by organic growth. During this process, while keeping their headquarters in high-income countries, many large firms have experienced massive asset restructuring in the global market-place. Thanks to the globalisation process and their supreme advantages in technology, capital, human resources, and market experiences, these large firms are able to upgrade their asset portfolios by selling off "non-core businesses" and concentrating on "core businesses." The emergence of industrial concentration has thus spread throughout all high-income countries and into large parts of the developing world. As a result, according to Nolan, wealth, technology, and business power have become significantly concentrated among a few huge firms in developed countries, but the growth 
prospects for these firms depend critically on building business within developing countries such as China.

However, despite China's rapid economic growth in the past few decades and its eagerness to rise (or, according to Nolan, "renaissance," as the country was the world's largest economy before the Industrial Revolution), "there is still a wide development gap between China and the high-income countries" (p. 66). China's huge population, tremendous environmental pressures, and widespread collective protests all constrict its indigenous development. In contrast, thanks to China's "reform and opening-up" policy, many multinational companies have successfully extended their organisations and influence into the world's largest emerging market. These firms may "have made a critically important contribution to China's growth and modernisation" (p. 93), yet their success in China primarily reinforces their own technological, financial, and marketing superiority. Conversely, due to adverse factors such as increasingly hostile international political circumstance, large Chinese firms remain mainly bound within the domestic economy. Despite the Chinese government's endeavours to promote a "going-out" policy for the country's leading companies, "Chinese firms have been conspicuously absent from major international mergers and acquisitions" (p. 98), and "the efforts of China's large firms to acquire businesses in the high-income countries have mostly ended in failure" (p. 99). As Nolan sharply points out, the scales of China's FDI and foreign exchange reserves are very small compared to those of major countries and funds in the developed world, and Chinese firms face numerous insurmountable obstacles as they try to extend their organisations and business influence into the high-income countries.

Nolan further elaborates on the blurring of boundaries between emerging Chinese companies and the established large firms of high-income countries in the fourth chapter. Taking typical examples from the banking and aerospace sectors, Nolan shows that major Western companies are heavily involved in some critical strategic industries in which China appears to be taking full control. Therefore, as the conclusion observes, most leading positions in the value chain are occupied by large firms from the high-income countries, and China is not anywhere near "buying the world" due to its technological, financial, and political disadvantages in global competition.

In spite of its brevity, this highly readable yet rigorous volume closely engages many essential issues that directly concern the future of the world's economic and political orders. There is, of course, much more to learn from the book beyond Nolan's insightful answers to the academically, politically, and practically important question in the book title. In fact, this book should be regarded as another excellent production of Nolan's fruitful academic career. Consistent with Nolan's many earlier works that demonstrate his expertise in areas of development, globalisation, and economic transition, this new book successfully highlights some crucial yet often neglected aspects of China's development; for example, while the conventional wisdom claims that China is taking over the world's markets through cheap labour, heavy pollution, intensive resource consumption, and unfair competition strategies backed by an authoritarian regime, Nolan finds that the real picture is much more complex, and he clearly features the many challenges and obstacles developing countries encounter in the course of catching up. Moreover, this book sheds new light on the dominant roles played by large firms in and beyond the world economy, and invites readers to reflect on the impacts of capitalist globalisation on the power relations between developed and developing countries. In fact, Nolan uses China as a typical case to illustrate the challenges that most developing countries have to face during their rise. In other words, this book adopts a comparative perspective in a single case study. As a result, while the author puts particular emphasis on China's distinguishing features, the academic and practical implements of this book are not limited to China. This is certainly a very successful volume that fully achieves the author's goals. However, inspired by such a fascinating book, interested readers may allow their thoughts to continue beyond the scope of the author's intentions. Yes, China is not buying the world and is unlikely to be able to do so in the near future, but the country's constant high rate of growth is, after all, significant to many people in and outside China. Therefore, a series of questions closely or distantly related to this book may also be worth thinking about:Will China's rapid economic growth last long, given the numerous challenges to its social stability and environmental sustainability? What does a richer and more powerful Chinese state mean to its own people, its neighbouring countries, its business partners, and its potential competitors? How can China effectively deliver its messages to the world? How can China better manage the world's impressions and expectations of it? How should the developed world interpret and accommodate China? What lessons should researchers and the general public learn from the rise of China? In an interview to promote his book, Nolan said that China's bureaucratic system is "stimulating, accepting, encouraging, but also regulating the market in a non-ideological fashion" with a high degree of professionalism. While such an argument is likely to be welcomed by scholars such as Sebastian Heilmann (2011), it may also have many sceptics, among them probably Yasheng Huang (2008) and Minxin Pei (2006). The debates over China's future development and impact will definitely continue as the country's influence continues to increase in the international arena.

\section{Yu Tao is a PhD candidate at the Department of Politics and International Relations in the University of Oxford (yu.tao@politics.ox.ac.uk).}

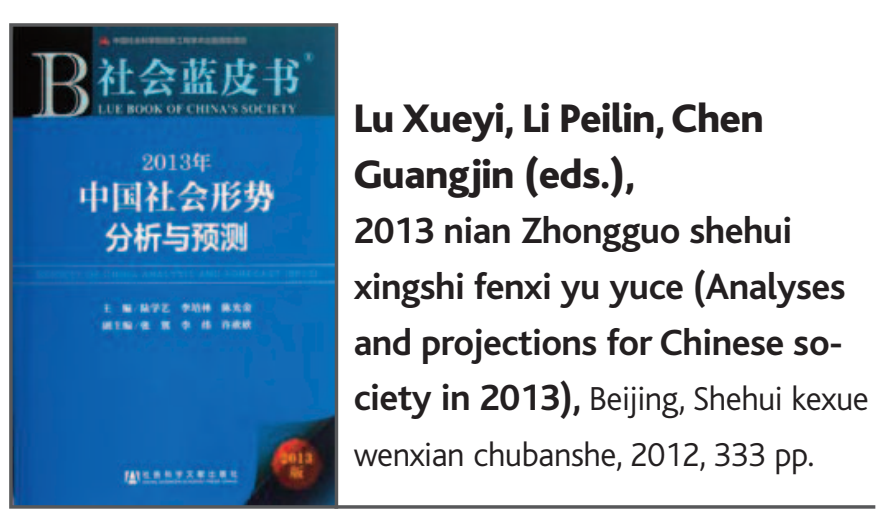

\section{AURÉLIEN BOUCHER}

$\mathrm{T}$ his volume is part of a "blue book" (lanpishu) collection. With 19 others published in 2013 - on subjects as diverse as education, the economy, and special economic zones - it must be seen as an official "report" (baogao), meant to make a first assessment of national and/or local public policies. Published since 1993, the blue book on "analyses and projections for Chinese society" is mostly the work of scholars from the Chinese Academy of Social Sciences (CASS). It is one of the missions of the academy, whose role consists of standing alongside the government in the "reform" process. Since early in the last decade, studies compiled by CASS have fo- 